\begin{tabular}{|c|c|}
\hline A & $\begin{array}{c}\text { International Journal of Current Research } \\
\text { and Academic Review }\end{array}$ \\
\hline $\begin{array}{l}\text { XECELLENT } \\
\text { UBLISHERS }\end{array}$ & $\begin{array}{c}\text { ISSN: 2347-3215 (Online) Volume } 7 \text { Number } 1 \text { (January-2019) } \\
\text { Journal homepage: http://www.ijcrar.com }\end{array}$ \\
\hline
\end{tabular}

doi: https://doi.org/10.20546/ijcrar.2019.701.006

\title{
The Role of Institutional Finance to Agriculture Sector in India
}

\author{
H.K. Dyavanaika* and S. Mokshapathy
}

Institute of Development Studies, University of Mysore, Manasagangothri, Mysuru-570 006, Karnataka, India

*Corresponding author

\begin{abstract}
The institutional agriculture finance has been important role play in agricultural development of India. in supply of institutional finance to agriculture many number of institutional agencies are involved in India, for the present study we have selected only of three Institutional agencies and they contribute such as Schedule Commercial Banks (76\%), Co-operative Banks (13\%) and Regional Rural Banks (11\%) it signifies that there is an increasing trend in institutional agriculture finance in India. The present study has reveals that the pattern, structure and the importance of institutional agriculture finance India. Institutional Agriculture credit has essentiality in purchase of improved seeds (such as HYVs), for adoption of new technology, land development, to have better and safe transportation, to have cold storage facility where has it helps the farmers to sale when prices of agricultural commodity is rise in the market. The quantum of loan avail to farmers that will affect the production and quality produce of agriculture. The present study suggested that instead of providing waive off of loan to farmers we have to provide essential perquisites to them such as Minimum Support Price, Storage facility, improved seeds and new technology, and we need to enhance the agricultural finance for keep sustainability of farmers as well as farmers due to now a day's agriculture is becoming no profitable area and agricultural farmers are becoming agriculture labors through sale of their land because they considered that it not profitability activity, in this situation the Government has to come forward and brought new policies like direct beneficiary schemes for effective reach of agricultural finance to the peasants. the farming community must be kept informed about various sources of institutional agriculture finance avail in different schemes and lastly The study has suggested simplification of the legal and regulatory procedures are liberal to access agriculture finance to the farming community because most of the farmers are illiterate.
\end{abstract}

\section{Introduction}

Agriculture plays a pivotal role in the development of Indian economy. Despite it relatively diminishing contribution to GDP, its accounts for $60 \%$ of employment and provides important raw materials to many industries and accounts for a significant share in total exports. Credit is one of the critical inputs for agricultural development. The role of institutional credit

\section{Article Info}

Accepted: 22 December 2018

Available Online: 20 January 2019

\section{Keywords}

Agriculture finance, Structure, Trends, Essentials, Its role in agriculture development. 
consecutive failure of monsoons, recurring droughts, mounting debts and lower production resulting too many farmers' suicides. In order to address these problems timely and adequate credit at affordable rate is imperative.

Indian farmer is characterized by seasonal agriculture income while his working expenses are spread overtime. With a small quantities of marketed surplus resulting to inadequate or no savings have severely hampered the farmers repayment capacity of loan. In this context, institutional credit plays a very crucial role in agriculture and rural economy, and any flaws in its delivery mechanism can cause cascading effects. In this backdrop, this paper focuses on the significance of agriculture and agricultural credit and discusses the measures adopted by the regulatory authorities to promote the agricultural credit over the years. Further, the paper also attempts to evaluate the performance of institutional credit to agriculture and also offers suggestions to improve the rural credit mechanism.

Finance in agriculture is as important as development of technologies. Technical inputs can be purchased and used by farmers only if sufficient money (funds) is available with farmers. Most of the times farmers suffer from the problem of inadequate financial state. This situation leads to borrowing from an easy and comfortable source.

Professional money lenders were the only source of credit to agriculture till 1935. They used to charge unduly exorbitant rates of interest and follow serious practices while giving loans and recovering them. As a result, farmers were heavily burdened with debts and many of them are left with perpetuated debts. There were widespread discontents among farmers against these practices and there were instances of riots also.

With the passing of Reserve Bank of India Act 1934, District Central Cooperative Banks and Land Development Banks, agricultural credit received impetus and there were improvements in agricultural credit. A powerful alternative agency came into being through the initiative of the government. Large-scale credit was available with reasonable rates of interest at easy terms, both in terms of granting loans and recovery of them. The cooperative banks advance credit mostly to agriculture. First bank advanced short-term and medium term loans while the second bank advanced long-term loans. The Reserve Bank of India as the Central bank of the country took lead in making credit available to agriculture through these banks by laying down suitable policies.

Although the cooperative banks started financing agriculture with their establishments in $1930^{\circ e} \mathrm{~s}$ real impetus was received only after Independence when suitable legislations were passed and policies were formulated. Thereafter, bank credit to agriculture has made a phenomenal progress by opening branches in rural areas and attracting deposits.

Till 14 major commercial banks were nationalized in 1969, cooperative banks were the main institutional agencies providing finance to agriculture. After nationalization, it was made mandatory for these banks to provide finance to agriculture as a priority sector. These banks undertook special programs of branch expansion and created a network of banking services throughout the country and started financing agriculture on large scale. Thus agriculture credit acquired multiagency dimension. In bringing "Green Revolution", "White Revolution" and now "Yellow Revolution" finance has played a crucial role. Now the agriculture credit, through multi agency approach has come to stay.

The procedures and amount of loans for various purposes have been standardized. Among the various purposes "Crop loan" (Short-term loan) has the major share. In addition, farmers get loans for the purchase of electric motor with pump, tractor and other machinery, digging wells or boring wells, installation of pipe lines, drip irrigation, planting fruit orchards, purchase of dairy animals and feeds/fodder for them, poultry, sheep/goat keeping and for many other allied enterprises.

"Agricultural finance is the study of financing and liquidity services credit provides to farm borrowers. It is also considered as the study of those financial intermediaries who provide loan funds to agriculture and the financial markets in which these intermediaries obtain their loanable funds.

\section{Importance of agriculture finance}

Agricultural production in this country depends upon millions of small farmers. Their intensity, effort and efficiency have helped in raising yields per acre. Finance in agriculture act as a key to farmers. But farmers ${ }^{\text {ee }}$ money is always inadequate and he needs outside finance or credit. Because of inadequate financial resources and absence of timely credit facilities at reasonable rates, many of the farmers are unable to go in for improved 
seeds and manures or to introduce better methods or techniques.

The farming community must be kept informed about the various sources of agriculture finance. Agricultural finance possesses its usefulness to the farmers, lenders and extension workers. The knowledge of lending institutions, their legal and regulatory environment helps in selecting the appropriate lender who can adequately provide the credit with terms and related services needed to finance the farm business.

\section{Role of agriculture finance}

Agriculture plays a crucial role in the development of the Indian economy. It accounts for about 17 per cent of GDP and about two thirds of the population is dependent on this sector. Agricultural finance is a subset of rural finance dedicated to financing agricultural related activities such as input supply, production, distribution, wholesale, processing and marketing. Financial service providers face distinct challenges when dealing with this sector. For example, the seasonal nature of production and the dependence on biological processes and natural resources leave producers subject to events beyond their control such as droughts, floods or diseases. The modern agriculture has increased the use of inputs especially for seed, fertilizers, irrigational water, machineries and implements, which has increased demand for agricultural credit. The adoption of modern technology, which is capital intensive, has commercialized agricultural production in India. Besides, the farmerse income is seasonal while his working expenses are spread over time. In addition, farmer's inadequate savings require the uses of more credit to meet the increasing capital requirements. Furthermore, credit is a unique resource, since it provides the opportunity to use additional inputs and capital items now and to pay for them from future earnings.

The rural population in India suffers from a great deal of indebtedness and is subject to exploitation in the credit market due to high interest rates and the lack of convenient access to credit. Rural households need credit for investing in agriculture and smoothening out seasonal fluctuations in earnings. Since cash flows and savings in rural areas for the majority of households are small, rural households typically tend to rely on credit. Rural households need access to financial institutions that can provide them with credit at lower rates and at reasonable terms than the traditional money-lender and thereby help them avoid debt-traps that are common in rural India.
Timely and adequate agricultural credit is important for the increase in fixed and working capital for farmers. In order to provide sufficient credit to the farmers, many institutional and non-institutional agencies are working. Under institutional agencies cooperative, commercial, regional rural banks and different Government organizations are supplying credit to the needy farmers on priority basis.

\section{Status of agriculture finance}

Credit in conjunction with modern agricultural technologies has ushered in the agricultural development across Indian regions. The liberal credit supply by the lending institutions enabled rapid infrastructural growth across and thereby improved the farm level credit absorption capacity. Although credit has played vital role in agricultural development yet regional and farmcategory wise disparity has also taken place. In fact, some of the states with better natural resource base have progressed well while some others lagged far behind. Likewise, some farmers with better resource endowments and access to financial and other institutions have marched faster while others could not do so. Furthermore, multiplicity of lending institutions together with the liberal deployment of credit through various ongoing schemes including micro-financing have saved rural dwellers from the clutches of money lenders. Yet, non-institutional credit agents still survive as they follow the canons of financing.

To analyzes the structure and trends of Agricultural financing in India.

To study the importance of Agricultural finance on agricultural development in India.

\section{Scope and limitations of the study}

The different institutions in India played very important role in financing agricultural sector in India. In this present study only Commercial Banks, Regional Rural Banks and Co-operative Banks are consider. For the purpose of study only secondary data are taken for Agency-wise Ground level Credit Flow for the year 2012-13 to 2017-18, share of SF/MF I Ground level Credit Flow to agriculture used for the year 2009-10 to 2017-18, Agency Disbursement of Refinance used for the year 2014-15 to 2017-18, Region-wise Disbursement of Refinance used for the year 2014-15 to 2017-18 and so all the limitations of secondary data are found in the study. 


\section{Review of literature}

Choubey (1983) examined the various institutions which are actively engaged in the task of financing agricultural sector. But after reviewing the impact of the institutional credit on agriculture, it has been observed by the author, that despite the complexity of institutions like Cooperatives, Commercial Banks, Regional Rural Bank and National Bank of Agriculture and Rural Development etc., the agriculture sector has been still suffering for want of adequate funds.

Deb and Rajeev (2007) while studying the credit pattern of borrowers form the formal sector in Hooghly district of West Bengal concluded that the entire set of medium farmers could avail loan within a period of one month, this percentage declined to 83 for the small farmers and 75 to the marginal ones. As these loans were crop loans, one can easily imagine the problem of disbursement.

Gowhar Bashir Ahangar et al., (2013) the institutional credit has been conceived to play an important role in the agricultural development of India. A large number of institutional agencies are involved in the disbursement of credit to agriculture. However, the persistence of money lenders in the rural credit market is still a major concern. In this backdrop, the present study has assess the quantum of loans issued and outstanding by institutional agencies and to examine the progress of Scheduled Commercial Banks in supplying agricultural credit in India. The relevant information was gathered through secondary data and compound growth rate were used for the analysis of data. The study reveals that the highest increase in loans issued was in the case of Scheduled Commercial Banks while the lowest was in the case of Co-operatives on the other hand the total number of account holders in scheduled commercial banks has increased from 5,841 to 30,538, whereas the amount of finance increased from 14,516 to $2,71,670$ in the referred period. The total direct and indirect advances to agriculture outstanding by scheduled commercial banks shown gradual increase from 59310 crore to 583343 crores during the reference period.

Aditya Banerjee et al., (2014) examined that agriculture has been a very important contributor to the GDP of Bhutan since the very beginning. Its contribution to the GDP has been recorded at $38 \%$ in the year 1995 with $85 \%$ of the population dependent upon it; the contribution was $35.9 \%$ in the year 2000 . Though the contribution of agriculture declined from $55 \%$ (1985) to
$33 \%$ (2003) of GDP, it still remains as a dominant factor in the economy of the country. But in the last decade, contribution of agriculture has fallen to $16.7 \%$ of GDP. The problem of achieving self reliance lies heavily on the shoulder of this sector as without development of the primary sector, the development of secondary sector and consequently, development of the nation cannot be achieved to the full. The decrease of approximately $50 \%$ in 10 years signals that this sector requires immediate attention. This study aims at identifying how, the establishment of specialized Financial Institutions for Agriculture like; 'National Bank for Agriculture and Rural Development' (NABARD, India), can help in developing this sector. This study strives to crystallize the role that such specialized institutions have to play, since they can provide customized solutions for different requirements in the agricultural sector of a country, in the form of structures, plans, schemes, policies and procedures, and expose the farmers to the modern technologies and methods of agriculture.

Anjani Kumar et al., (2010) the institutional credit has been conceived to play a pivotal role in the agricultural development of India. A large number of institutional agencies are involved in the disbursement of credit to agriculture. However, the persistence of money lenders in the rural credit market is still a major concern. In this backdrop, their $\mathrm{t}$ study has examined the performance of agricultural credit flow and has identified the determinants of increased use of institutional credit at the farm household level in India. The study has revealed that the institutional credit to agriculture in real terms has increased tremendously during the past four decades. The structure of credit outlets has witnessed a significant change and commercial banks have emerged as the major source of institutional credit in recent years. But, the declining share of investment credit in the total credit may constrain the sustainable agricultural growth. The quantum of institutional credit availed by the farming households is affected by a number of sociodemographic factors which include education, farm size, family size, caste, gender, occupation of household, etc. The study has suggested simplification of the procedure for a better access to agricultural credit of smallholders and less-educated/illiterate farmers.

\section{Materials and Methods}

This study was mainly focused on progress, pattern, trends and essentials of institutional credit to agricultural sector in India. The time series data on institutional 
credit in India to agricultural sector where collected from the following published sources.

Reserve Bank of India, Government of India, Department of Agriculture and Co-operation, Government of Karnataka, Department of Agriculture and Food Production, Board of Revenue, Department of planning and Co-operation, Bureau of Statistics Karnataka and Other Institutions, NABARD Annual Report, Alamance Sheet, Profit and Loss Account and Cash Flow of NABARD, Debt and Investment Survey Report of India and various published articles on institutional finance used for the present study.

\section{Tools of analysis}

The following tools were employed to analyse the data with reference to selected objectives of this study:

Percentage variation,

Percentage growth

\section{Results and Discussions}

During 2016-17, banks had disbursed Rs. 9,59,826 crore (provisional as on 28 February 2017) credit to the agriculture sector (including agriculture and allied, agriinfrastructure and ancillary activities), against a target of
Rs. 9,00,000 crore. Commercial banks, Regional Rural Banks (RRBs) and cooperative banks disbursed (provisional) Rs. 7,33,201 crore, Rs.1,03,974 crore and Rs. 1,22,651 crore, respectively (Tabel.1.1.)

From the above (Table and Figure 1.2.) clearly described that Ground-level Disbursement to Agricultural Sector, the category of Crop and term loan, Both Crop and Term loans are indicating increasing in trend for given period of 2012-13 to 2016-17, out of Rs. 8,77,224 crores, Crop loan disbursed Rs. 7,05,443 Crores and Rs. 1,71,781 as Term loan respectively during the

Year2016-17.

Clearly, there is an improvement in the SF/MF share both in terms of number of accounts as well as loan disbursed by all the agencies as revealed by a comparison of the situation in 2016- 17 over 2009-10. Nevertheless, the SF/MF community still depends largely on cooperative banks and RRBs. Even with an enlarged share over the years, commercial banks still dedicate less than one-third of their total agriculture loan portfolio to SF/MF category, while the same for cooperative banks is more than half and RRBs, about two-thirds in 2016-17. Thus, cooperatives and RRBs are better purveying mechanism than commercial banks when it comes to serving the small and marginal farmers, both in physical and financial terms. (Table 1.3.).

Tabel.1 Agency-wise ground-level credit flow

\begin{tabular}{|c|c|c|c|c|c|}
\hline Agency & 2012-13 & 2013-14 & 2014-15 & $\begin{array}{l}\text { 2015-16 } \\
\text { (Provisional) }\end{array}$ & $\begin{array}{l}2016-17 \text { (Provisional } \\
\text { as on) 28.02.2017) }\end{array}$ \\
\hline Cooperative Banks & $4,32,491$ & $5,27,506$ & $1,38,469.5$ & $1,53,294.98$ & $1,22,651.25$ \\
\hline RRBs & 63,681 & 82,653 & $1,02,482.91$ & $1,19,260.88$ & $1,03,973.52$ \\
\hline SCBs & $1,11,203$ & $1,19,964$ & $6,04,375.82$ & $6,42,954.06$ & $7,33,200.93$ \\
\hline Total & $6,07,375$ & $7,30,123$ & $8,45,328.23$ & $9,15,509.92$ & 9,59,825.7 \\
\hline
\end{tabular}

Sources: Annual Report of NABARD 2016-17

Table.2 Ground-level Disbursement to Agricultural Sector

\begin{tabular}{|l|c|c|c|r|c|}
\hline Category & $\mathbf{2 0 1 2}-13$ & $\mathbf{2 0 1 3 - 1 4}$ & $\mathbf{2 0 1 4 - 1 5}$ & $\mathbf{2 0 1 5 - 1 6}$ & \multicolumn{1}{|c|}{$\mathbf{2 0 1 6 - 1 7}$} \\
\hline Crop loans & $3,96,158$ & $4,73,500$ & $5,48,435$ & $6,35,412$ & $7,05,443$ \\
\hline Term loans & $1,14,871$ & $1,33,875$ & $1,81,688$ & $2,09,916$ & $1,71,781$ \\
\hline Total & $\mathbf{5 , 1 1 , 0 2 9}$ & $\mathbf{6 , 0 7 , 3 7 5}$ & $\mathbf{7 , 3 0 , 1 2 3}$ & $\mathbf{8 , 4 5 , 3 2 8}$ & $\mathbf{8 , 7 7 , 2 2 4}$ \\
\hline
\end{tabular}

Sources: Annual Report of NABARD 2016-17 
Table.3 Share of SF/ MF in Ground Level Credit Flow to Agriculture (2009-10 and 2016-17)

\begin{tabular}{|c|c|c|c|c|c|c|c|c|c|c|}
\hline \multirow{3}{*}{ Agency } & \multicolumn{5}{|r|}{$2009-10$} & \multicolumn{5}{|r|}{ 2016-17 } \\
\hline & \multicolumn{2}{|c|}{$\begin{array}{l}\text { No of accounts } \\
\text { (Lakh) }\end{array}$} & \multicolumn{2}{|c|}{$\begin{array}{l}\text { Loan disbursed } \\
\text { (Rs. Crores) }\end{array}$} & \multirow{2}{*}{$\begin{array}{c}\text { Avg loan } \\
\text { amount of } \\
\text { SM/MF (Rs) }\end{array}$} & \multicolumn{2}{|c|}{$\begin{array}{c}\text { No of accounts } \\
\text { (Lakh) }\end{array}$} & \multicolumn{2}{|c|}{$\begin{array}{c}\text { Loan disbursed (Rs. } \\
\text { Crores) }\end{array}$} & \multirow{2}{*}{$\begin{array}{c}\text { avg loan } \\
\text { amount of } \\
\text { SM/MF (Rs) }\end{array}$} \\
\hline & Total & SF/MF & Total & SF/MF & & Total & SF/MF & Total & SF/MF & \\
\hline $\begin{array}{l}\text { Cooperative } \\
\text { Banks }\end{array}$ & 201.8 & $\begin{array}{r}117.9 \\
(58.4)\end{array}$ & 48,258 & $\begin{array}{c}22,609 \\
(46.9)\end{array}$ & 19,176 & 306.9 & $\begin{array}{l}202.8 \\
(66.1)\end{array}$ & $1,38,470$ & $\begin{array}{c}78,736 \\
(56.9) \\
\end{array}$ & 38,830 \\
\hline Total & 439.3 & $\begin{array}{l}257.5 \\
(58.6)\end{array}$ & $2,54,658$ & $\begin{array}{l}89,859 \\
(35.3)\end{array}$ & 34,897 & 853.6 & $\begin{array}{l}486.0 \\
(56.9)\end{array}$ & $8,45,328$ & $\begin{array}{c}3,46,666 \\
(41.0)\end{array}$ & 71,326 \\
\hline
\end{tabular}

Source: Corporate Planning Department, NABARD, Mumbai (compiled from reports collected from IBA, Cooperative banks and RRBs)

Table.4 Agency-wise Disbursement of Refinance

\begin{tabular}{|c|c|c|c|c|c|c|}
\hline \multirow{2}{*}{ Agency } & \multicolumn{2}{|c|}{ 2014-15 } & \multicolumn{2}{|c|}{ 2015-16 } & \multicolumn{2}{|c|}{$\begin{array}{l}\text { (Amount in Rs. Crores } \\
\mathbf{2 0 1 6 - 1 7}\end{array}$} \\
\hline & Disbursed & Share $(\%)$ & Disbursed & Share $(\%)$ & Disbursed & Share $(\%)$ \\
\hline $\mathrm{SCBs}$ & $\begin{array}{c}13,254.62 \\
(8,500.00)\end{array}$ & $\begin{array}{c}61.69 \\
(50.03) \\
\end{array}$ & $\begin{array}{l}13,675.20 \\
(9,900.00)\end{array}$ & $\begin{array}{c}43.51 \\
(39.62) \\
\end{array}$ & $\begin{array}{c}22,823.54 \\
(20,000.00)\end{array}$ & $\begin{array}{c}47.49 \\
(44.45) \\
\end{array}$ \\
\hline RRBs & $\begin{array}{c}4,303.66 \\
(3,915.00) \\
\end{array}$ & $\begin{array}{c}20.03 \\
(23.04) \\
\end{array}$ & $\begin{array}{l}10,220.91 \\
(8,000.00) \\
\end{array}$ & $\begin{array}{c}32.52 \\
(32.01) \\
\end{array}$ & $\begin{array}{c}12,139.68 \\
(13,699.00)\end{array}$ & $\begin{array}{c}25.26 \\
(30.44) \\
\end{array}$ \\
\hline $\mathrm{StCBs}$ & $\begin{array}{c}1,713.32 \\
(1,975.00)\end{array}$ & $\begin{array}{c}7.97 \\
(11.62) \\
\end{array}$ & $\begin{array}{c}3,818.09 \\
(3,500.00)\end{array}$ & $\begin{array}{c}12.15 \\
(14.01) \\
\end{array}$ & $\begin{array}{c}6,231.12 \\
(5,000.00)\end{array}$ & $\begin{array}{c}12.96 \\
(11.11) \\
\end{array}$ \\
\hline SCARDBs & $\begin{array}{c}1,814.95 \\
(2,000.00) \\
\end{array}$ & $\begin{array}{c}8.45 \\
(11.77) \\
\end{array}$ & $\begin{array}{c}2,923.97 \\
(2,600.00) \\
\end{array}$ & $\begin{array}{c}9.30 \\
(10.40) \\
\end{array}$ & $\begin{array}{c}3,258.26 \\
(3,200.00)\end{array}$ & $\begin{array}{c}6.78 \\
(7.11) \\
\end{array}$ \\
\hline PUCBs & $\begin{array}{c}30.00 \\
(100.00)\end{array}$ & $\begin{array}{c}0.14 \\
(0.59) \\
\end{array}$ & $\begin{array}{c}0.00 \\
(100.00) \\
\end{array}$ & $\begin{array}{c}0.00 \\
(0.40) \\
\end{array}$ & $\begin{array}{c}0.00 \\
(0.00) \\
\end{array}$ & $\begin{array}{c}0.00 \\
(0.00)\end{array}$ \\
\hline $\begin{array}{l}\text { NABARD } \\
\text { subsidiaries }\end{array}$ & $\begin{array}{c}369.61 \\
(500.00) \\
\end{array}$ & $\begin{array}{c}1.72 \\
(2.94) \\
\end{array}$ & $\begin{array}{c}489.13 \\
(490.00) \\
\end{array}$ & $\begin{array}{c}1.56 \\
(1.96) \\
\end{array}$ & $\begin{array}{c}611.12 \\
(600.00)\end{array}$ & $\begin{array}{c}1.27 \\
(1.33) \\
\end{array}$ \\
\hline NBFCs & $\begin{array}{c}0.00 \\
(0.00)\end{array}$ & $\begin{array}{c}0.00 \\
(0.00)\end{array}$ & $\begin{array}{c}300.00 \\
(400.00)\end{array}$ & $\begin{array}{c}0.95 \\
(1.60)\end{array}$ & $\begin{array}{c}3,000.00 \\
(2,500.00)\end{array}$ & $\begin{array}{c}6.24 \\
(5.56)\end{array}$ \\
\hline Total & $\begin{array}{c}21,486.17 \\
(16,990)\end{array}$ & $\begin{array}{c}100.00 \\
(100)\end{array}$ & $\begin{array}{c}31,427.30 \\
(24,990)\end{array}$ & $\begin{array}{c}100.00 \\
(100)\end{array}$ & $\begin{array}{c}48,063.72 \\
(44,999)\end{array}$ & $\begin{array}{c}100.00 \\
(100)\end{array}$ \\
\hline
\end{tabular}

Source: NABARD Annual Report 2016-17 
Table.5 Region-wise Disbursement of Refinance

(Amount in Rs. Crores)

\begin{tabular}{|l|c|c|c|c|c|c|}
\hline \multirow{2}{*}{\multicolumn{1}{|c|}{ Region }} & \multicolumn{2}{|c|}{$\mathbf{2 0 1 4 - 1 5}$} & \multicolumn{2}{c|}{$\mathbf{2 0 1 5 - 1 6}$} & \multicolumn{2}{c|}{$\mathbf{2 0 1 6 - 1 7}$} \\
\cline { 2 - 7 } & Disbursed & $\begin{array}{c}\text { Share } \\
(\boldsymbol{\%})\end{array}$ & Disbursed & $\begin{array}{c}\text { Share } \\
(\boldsymbol{\%})\end{array}$ & Disbursed & $\begin{array}{c}\text { Share } \\
(\%)\end{array}$ \\
\hline Northern & $4,411.74$ & 20.53 & $5,260.99$ & 16.70 & $7,106.08$ & 14.80 \\
\hline North Eastern & 171.72 & 0.80 & 385.45 & 1.20 & 481.37 & 1.00 \\
\hline Eastern & $1,833.15$ & 8.53 & $3,711.66$ & 11.80 & $5,500.73$ & 11.40 \\
\hline Central & $1,804.04$ & 8.40 & $3,131.63$ & 10.00 & $4,498.64$ & 9.40 \\
\hline Western & $3,058.84$ & 14.24 & $4,951.66$ & 15.80 & $6,812.78$ & 14.20 \\
\hline Southern & $10,206.68$ & 47.50 & $1,3985.92$ & 44.50 & $23,664.12$ & 49.20 \\
\hline Total & $\mathbf{2 1 , 4 8 6 . 1 7}$ & $\mathbf{1 0 0 . 0 0}$ & $\mathbf{3 1 , 4 2 7 . 3 0}$ & $\mathbf{1 0 0 . 0 0}$ & $\mathbf{4 8 , 0 6 3 . 7 2}$ & $\mathbf{1 0 0 . 0 0}$ \\
\hline
\end{tabular}

Source: NABARD Annual Report 2016-17

Table.6 Purpose-wise Disbursement of Refinance

(Amount in Rs. Crores)

\begin{tabular}{|l|c|c|c|c|c|c|}
\hline \multirow{2}{*}{\multicolumn{1}{|c|}{ Purpose }} & \multicolumn{2}{|c|}{$\mathbf{2 0 1 4 - 1 5}$} & \multicolumn{2}{c|}{$\mathbf{2 0 1 5 - 1 6}$} & \multicolumn{2}{c|}{$\mathbf{2 0 1 6 - 1 7}$} \\
\cline { 2 - 7 } & Disbursed & $\begin{array}{c}\text { Share } \\
(\boldsymbol{\%})\end{array}$ & Disbursed & $\begin{array}{c}\text { Share } \\
(\boldsymbol{\%})\end{array}$ & Disbursed & $\begin{array}{c}\text { Share } \\
(\%)\end{array}$ \\
\hline Minor irrigation & 517.87 & 2.41 & $1,147.17$ & 3.65 & $1,174.30$ & 2.44 \\
\hline Land development & 834.05 & 3.88 & $1,300.16$ & 4.14 & $1,554.50$ & 3.23 \\
\hline Farm mechanizations & $3,062.40$ & 14.25 & $2,383.60$ & 7.59 & $5,672.29$ & 11.80 \\
\hline $\begin{array}{l}\text { Plantation and } \\
\text { horticulture }\end{array}$ & 690.59 & 3.21 & $2,033.45$ & 6.47 & $1,983.37$ & 4.13 \\
\hline PF/SGP/ AH-Other & 620.59 & 2.89 & 672.52 & 2.14 & $1,237.16$ & 2.57 \\
\hline Fisheries & 21.81 & 0.10 & 64.15 & 0.20 & 370.52 & 0.77 \\
\hline Dairy development & 931.89 & 4.34 & $1,770.63$ & 5.62 & $2,833.98$ & 5.90 \\
\hline Forestry & 6.39 & 0.03 & 8.29 & 0.03 & 5.90 & 0.01 \\
\hline $\begin{array}{l}\text { Storage godown and } \\
\text { market yard }\end{array}$ & 379.32 & 1.77 & 294.21 & 0.94 & 413.37 & 0.86 \\
\hline $\begin{array}{l}\text { Swarnajayanti Gram } \\
\text { Swarojgar Yojana }\end{array}$ & 54.96 & 0.26 & 0.81 & 0.003 & 0.49 & 0.00 \\
\hline Non-farm sector & $7,806.46$ & 36.33 & $11,117.83$ & 35.38 & $14,055.88$ & 29.24 \\
\hline SC/ST-AP & 14.70 & 0.07 & 2.47 & 0.007 & 36.14 & 0.08 \\
\hline SHG & $3,745.83$ & 17.43 & $4,493.67$ & 14.29 & $6,906.02$ & 14.37 \\
\hline Others & $2,799.32$ & 13.03 & $6,138.34$ & 19.54 & $11,819.80$ & 24.59 \\
\hline Total & $\mathbf{2 1 , 4 8 6 . 1 7}$ & $\mathbf{1 0 0 . 0 0}$ & $\mathbf{3 1 , 4 2 7 . 3 0}$ & $\mathbf{1 0 0 . 0 0}$ & $\mathbf{4 8 , 0 6 3 . 7 2}$ & $\mathbf{1 0 0 . 0 0}$ \\
\hline
\end{tabular}

Source: NABARD Annual Report 2016-17 
Table.7 State-wise Direct Lending Disbursement (Amount in Rs. Crores)

\begin{tabular}{|l|l|l|}
\hline States & Sanctioned & Disbursed \\
\hline Andhra Pradesh & 400 & 420 \\
\hline Gujarat & 695 & 620 \\
\hline Haryana & 495 & 178 \\
\hline Karnataka & 425 & 646 \\
\hline Kerala & 100 & 75 \\
\hline Maharashtra & 815 & 720 \\
\hline Madhya Pradesh & 2,460 & 653 \\
\hline Rajasthan & 589 & 488 \\
\hline Telangana & 450 & 480 \\
\hline Uttarakhand & 45 & 0 \\
\hline Uttar Pradesh & 1230 & 910 \\
\hline Bihar & 5 & 0 \\
\hline Himachal Pradesh & 100 & 100 \\
\hline Odisha & 150 & 150 \\
\hline Punjab & 00 & 100 \\
\hline Total & 7,959 & 5,540 \\
\hline
\end{tabular}

Source: NABARD Annual Report 2016-17

Figure.1 Agency wise credit flow to agriculture

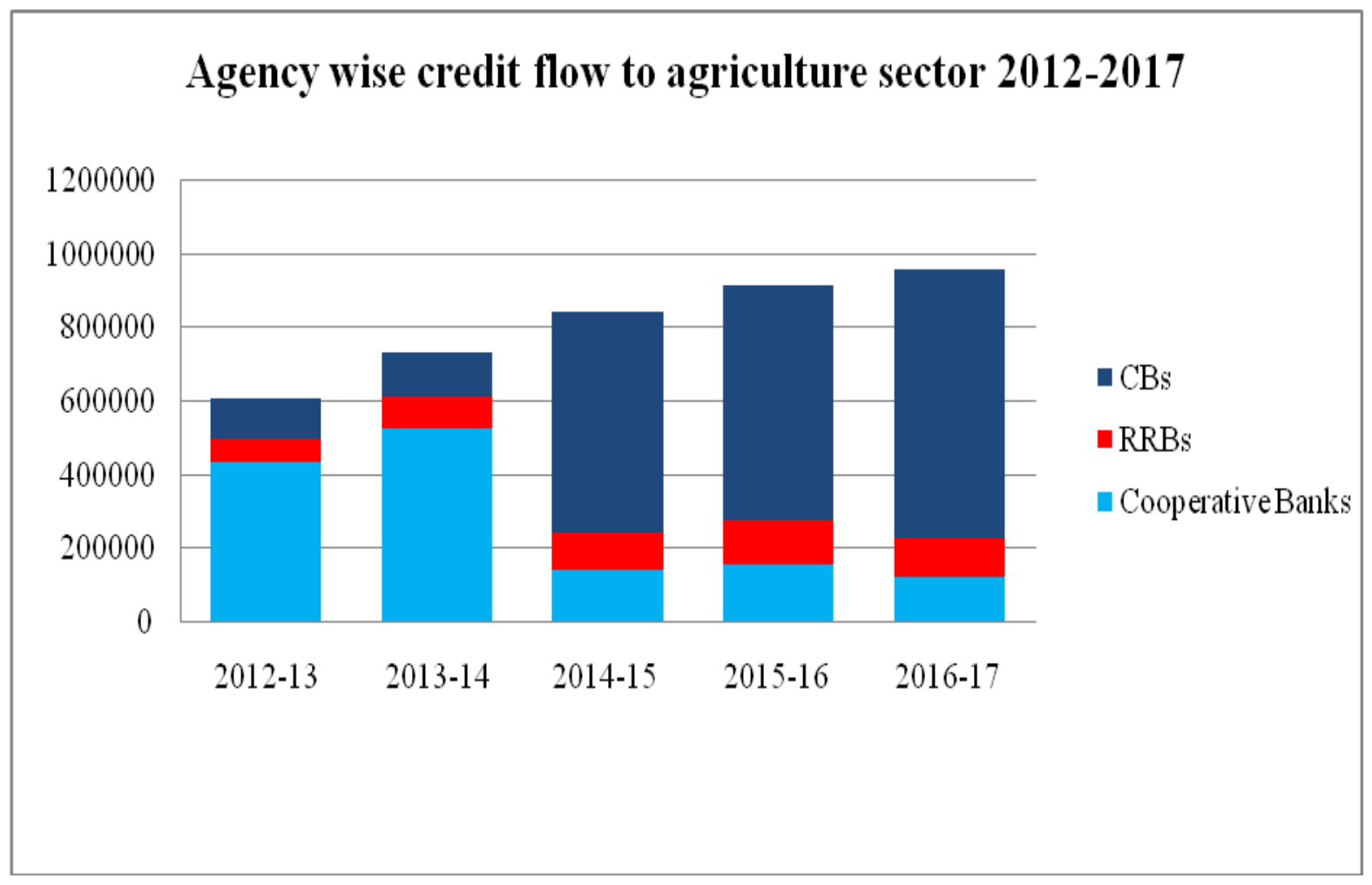


Figure.2 Ground level Disbarment to Agriculture

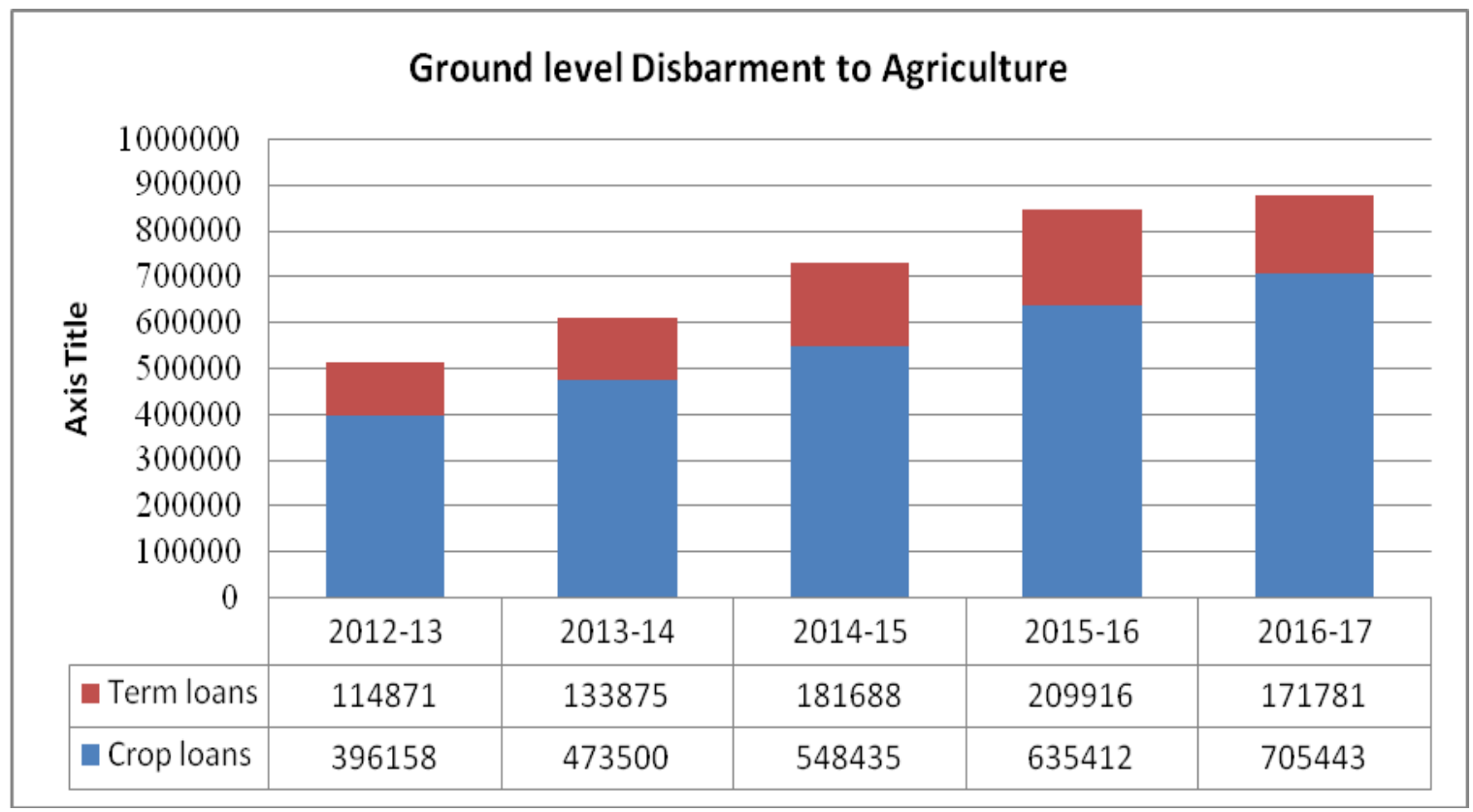

The increased GLC towards SF/ MF was attained more through credit deepening than widening. This was sharper in case of commercial banks. Despite increases in the number of holdings and expanding share in total area under cultivation there is no concomitant growth in GLC to SF/MF. Therefore it is imperative to bring down the barriers to SF/MF lending and for the social face of banking to view SF/MF lending favorably so that timely and affordable credit to this resource limited group can promote inclusive growth.

During 2016-17, out of the total disbursements of Rs. $48,063.72$ crore, the maximum share of 47.49 per cent went to SCBs, followed by RRBs (25.26 per cent), StCBs (12.96 per cent), SCARDBs (6.78 per cent), NBFCs (6.24 per cent), and NABARD Subsidiaries (1.27 per cent). All the agencies showed an upward growth trend in the last 3 years except PUCB (Table 1.4).

The spatial distribution of LT refinance disbursement indicates that a major share has gone to the states from the southern region (49 per cent), followed by northern (15 per cent), western (14 per cent), eastern (11 per cent), central (10 per cent) and north-eastern ( 1 per cent) regions (Table 1.5).

Non-farm sector (NFS) activities accounted for a major chunk of refinance with over 29 per cent share followed by SHGs (14 per cent), farm mechanization (12 per cent), dairy development (6 per cent), and plantation and horticulture (4 per cent) as the other major purposes for which LT credit was disbursed (Table 1.6.).

During 2016-17, NABARD had sanctioned Rs. 7,959 crore to 50 DCCBs and 8 StCBs including Rs. 550 crore sanctioned to one StCB and four DCCBs against pledge of sugar stocks of cooperative and private sugar factories. The disbursement for the period stood at Rs. 5,540 crore (Table 1.7.). The quantum of outstanding under this line of credit stood at over Rs. 3,251 crore as on 31 March 2017.

In conclusion, the study reveals that the institutional finance in India to agricultural sector has been increased in quantum of amount and disbursement, the finance provided by institutional agencies are increased its advances to the peasant in India, the study shows that three major institutions are providing agricultural sector namely Schedule Commercial Banks (76\%), Cooperative Banks (13\%) and Regional Rural Banks (11\%) this signifies that Government taking initiation through making policies and Financial Institutions are showing interest to provide agricultural finance to farmers in this study. The pattern and structure of agricultural finance has to modify in supply of agricultural finance through involvement of Central or Local (State) Government. Major problem in access of agricultural credit is having less awareness among the farmers, in order to create awareness to get agricultural credit government or banking institutions are come in to 
forward. The Institutional fiancé to agriculture having essentiality for production, marketing, to avoid moneylenders, land development, adopt modern technology, built Godown and to have cold storage facility etc., where in India have more small and marginal farmers they have to provide timely and adequate agricultural loan to keep their interest to produce and sustain of agriculture and keep going of nation development.

\section{References}

Anjani Kumar. (2010). "Institutional Credit to Agriculture Sector in India: Status, Performance and Determinants.” Pp. 253-264. Tamilnadu.

Annual Report 2016-17 (Ministry of Finance, Government of India)

Annual Report of NABARD 2016-17

Ashish Dhar Mishra. (2015). "An analysis of the role of bank credit in development of agriculture sector

\section{How to cite this article:}

Dyavanaika, H.K. and Mokshapathy, S. 2019. The Role of Institutional Finance to Agriculture Sector in India.

Int.J.Curr.Res.Aca.Rev. 7(1), 51-60. doi: https://doi.org/10.20546/ijcrar.2019.701.006 in Bihar with special reference to west champaran District” ISSN: 2277-1166. Agra.

Devaraja T.S. (2010). "An Analysis of Institutional Financing and Agricultural Credit Policy in India" Mysuru.

Gowhar Bashir Ahangar. (2013). "A study on institutional credit to agriculture sector in India" ISSN: 2347-3215. Coimbatore.

Rajiben Solanki. (2016). "A Study of Agricultural Finance by Commercial Banks in India: A case study of Central Bank of India" ISSN: 22771166. Saurashtra.

Ratan Lal Godara. (2014). "Agriculture Credit in India: An Analytical Study" ISSN: 2279-621X. Patan, Gujarat.

www.rbi.org.in

www.sbi.com

www.wikkipedia.com

Yojana 2018 